\title{
Effect of Different Plant Establishment Techniques on Yield and Yield Components of Rice (Oryza sativa L.) Varieties in East \& South East Coastal Plain of Odisha, India
}

\author{
Kamlesh Kumar Sahu $^{1 *}$, Bhirendra Kumar ${ }^{1}$, Uttam Kumar Diwan ${ }^{2}$ and S. Pasupalk ${ }^{3}$ \\ ${ }^{1}$ Department of Agrometerology, Odisha University of Agriculture and Technology, \\ Bhubaneshwar, Odisha, India \\ ${ }^{2}$ Indira Gandhi Krishi Vishwavidyalaya, Raipur, Chhattisgarh, India \\ ${ }^{3}$ Department of Agrometerology, (VC) Odisha University of Agriculture and Technology, \\ Bhubaneshwar, Odisha, India \\ *Corresponding author
}

\begin{abstract}
A B S T R A C T
The field experiment was conducted during kharif season of 2015 at research farm of College of Agriculture, Orissa University of Agriculture and Technology, Bhubaneswar,

Keywords

Rice, Naveen, Pooja, puddled, Unpuddled transplanting, Direct seeding

Article Info

Accepted:

28 June 2018

Available Online:

10 July 2018

Odisha to find out the effect of planting techniques on yield and yield component of two rice cultivars (Naveen and Pooja) under two dates of Sowing $\left(27^{\text {th }}\right.$ June and $11^{\text {th }}$ July) as three establishment methods (Direct seeding, unpuddled transplanting, puddled transplanting). The experiment was designed in Split-Split Plot Deign with establishment methods in main plots dates of sowing in sub plot and varieties as sub-sub plot treatment with three replications. There were 12 treatment combinations consisting of three establishment methods, two dates of sowing and two rice varieties. The other common packages of practices were followed time to time and periodically are observations were recorded on growth and yield for evaluate the treatment effects. The results observed in this experiment indicate that transplanted puddled rice registered maximum grain yield (3483kg/ha) as compared to unpuddled transplanted rice and direct seeded rice. The highest grain yield was obtained with $c v$. 'Pooja' $(3069 \mathrm{~kg} / \mathrm{ha})$ while the early sown crop ( $27^{\text {th }}$ June) produced maximum grain yield $(3117 \mathrm{~kg} / \mathrm{ha})$ than that crop sown in later $\left(11^{\text {th }}\right.$ July).
\end{abstract}

\section{Introduction}

Rice (Oryza sativa L.) is main livelihood of rural population and it is the most important staple food crop for more than half of the world's population, including regions of high population density and rapid growth. It provides about 21 per cent of the total calorie intake of the world population. Globally rice is grown in $162.3 \mathrm{mha}$, and India accounts for $27.47 \%$ with a cultivated area of $44.6 \mathrm{mha}$, the corresponding production being 738.1 and $104.20 \mathrm{mt}$. The average production under Indian condition is $2.44 \mathrm{t} \mathrm{ha}^{-1}$ compared to the world's average of $4.5 \mathrm{t} \mathrm{ha}^{-1}$ (CACP2015). Odisha occupies an area of $4.41 \mathrm{~m}$ ha 
producing $6.94 \mathrm{mt}$ with an average productivity of $1.57 \mathrm{t} \mathrm{ha}^{-1}, 35.56 \%$ less than the national average (Govt. of Odisha, 201213).

Transplanting is the most dominant and traditional method of establishment in irrigated low land rice. The area under transplanted rice in world is decreasing due to scarcity of water and labour. So, there is need to search for alternate crop establishment methods to increase the productivity of rice (Farooq, 2011).

Transplanting in puddle soil is the most dominant and traditional method of establishment in irrigated low land rice. Puddling, the typical pre planting management practice, is done to reduce water infiltration and to maintain the standing water in the field, which helps in weed management and facilitates easier transplanting (Sharma and De data, 1986) The depth of the water influences the type and density of weed flora (Kent and Jonson, 2001, Kumar and Ladha, 2011). Besides water management, tillage can also influence weed emergence due to changes in the mechanical characteristics(bulk density, penetration resistance, aggregate mean weight diameter and surface roughness) of the seedbed (Carman, 1996) as well as the vertical distribution of seeds in soil(Chauhan and Johnson, 2009). Puddled flooded Soil has many other benefits such as neutralising soil $\mathrm{p}^{\mathrm{H}}$, improving the availability of plant nutrients ( $\mathrm{P}, \mathrm{K}, \mathrm{Ca}, \mathrm{Mg}, \mathrm{Mn}$ and $\mathrm{Fe}$ ) and allowing for the accumulation of organic matter (Poonamperuma, 1972; Sahrawat, 2005). Mainly the indirect increase in the availability of nutrient by puddling is through the reduction of cation leaching (Aggarwal et al., 1995). In spite of all such advantages, puddling in rice associated with many problem of the soil structure, creation of hard Pan, increased methane emission, increased bulk density and soil compaction (Kirchhof et al.,
2000). Moreover puddling and transplanting also requires large amount of scarce water resources as well as labour (Kumar and Ladha, 2011).The puddling rice transplanting operations consumes about $25 \%$ of the total water required for rice during the growing sseason. The destruction of soil structure and formation of hard pan during puddling may have adverse effects on the growth and yield of subsequent non rice crop in the relation and these crops also require more energy for field preparation (Kumar and Ladha, 2011).

Under the context of looming water, labour scarcity and deteriorated soil structure due to puddling, there is an urgent need to replace conventional transplanting method of rice with non-puddled transplanting (NPTR) or direct seeding (DSR). DSR saves water and labour (by avoiding puddling of soil, nursery management and planting operation), shorter the crop duration by 7 to 10 days and can produce as much grain yield as that of transplanted crop needs only $34 \%$ of the total labour requirement and saves $29 \%$ of the total cost of the transplanted crops (Ho and Romil, 2000).

Direct seeding allows early establishment of the succeeding crop and higher profit in areas with assured supplies by utilizing short duration modern varieties and most efficient herbicide (Balsubramanian and Hill, 2002). Date of sowing /planting is also having significant influence on rice, Early planting on $25^{\text {th }}$ June (Mukesh et al., 2013) and on $10^{\text {th }}$ July (Maiti and Khan, 2007) have positive impacts on growth and yield of rice. Besides, varietal difference also exists under different dates of sowing and rice establishment methods. The information on the effect of different rice establishment method on the promising varieties of Odisha under different dates of sowing are meagre. Keeping these things in view the present study was designed to study the aforesaid objective. 


\section{Materials and Methods}

The present investigation was carried out during kharif season of 2015 at Research farm of College of Agriculture, Orissa University of Agriculture and Technology, Bhubaneswar, situated at an elevation of $25.9 \mathrm{~m}$ above mean sea level at $20^{\circ} 15^{\prime} \mathrm{N}$ latitude and $85^{\circ} 52^{\prime} \mathrm{E}$ longitude. It is in the East \& South East Coastal Plain of Odisha, which falls under Tropical wet-dry or Tropical Savanna. The general climatic condition of Bhubaneswar is hot and humid. The annual mean temperature is $27.4{ }^{\circ} \mathrm{C}$. Mean monthly temperatures range from 22 to $32^{\circ} \mathrm{C}$. Summer season (March to June) is hot and humid, with temperatures ranging $30-40{ }^{\circ} \mathrm{C}$. Winter season (December and January) lasts for about ten week. Atmospheric humidity is normally higher during June to September thereafter, decreases during rabi with increased sunshine hours. It gets mean annual Rainfall of about $1,542 \mathrm{~mm}$ of which nearly $80 \%$ from SW monsoon during the month of June to September. Highest monthly rainfall occurs in month of August which is about $330 \mathrm{~mm}$. The experiment was laid out in a Split-Split Plot Deign with establishment methods in main plots dates of sowing and sub plot varieties as sub-sub plot treatment. The dimension of the experimental area was $26 \mathrm{~m} \times 28 \mathrm{~m}\left(728 \mathrm{~m}^{2}\right)$ with each plot dimension of $4 \mathrm{~m} \times 3.8 \mathrm{~m}$ $\left(15.2 \mathrm{~m}^{2}\right)$. The experimental plot was provided with irrigation channels and the individual plots were demarcated with bunds. There were 12 treatment combinations consisting of three establishment methods, two dates of sowing and two rice varieties. The details of the treatment combinations are given in table 1 . A seed rate of $5 \mathrm{gm} / \mathrm{m}^{2}$ was used for nursery raising of the crop and $7 \mathrm{gm} / \mathrm{m}^{2}$ for direct sowing of the crop in different plots. The presoaked seeds were sown in the raised nursery bed by broadcasting method using $5 \mathrm{~g}$ seeds $\mathrm{m}^{-2}$ or $300 \mathrm{~g}$ seeds per plot per variety. Light and frequent irrigations were given during dry spells until the seedlings were ready for transplanting. After puddling and leveling operation FYM was applied at the rate of 10 $\mathrm{kg}$ per plot. Finally transplanting of seedlings were carried out. Fifteen days old seedlings were transplanted in the field at 1-2 seedlings per hill. In case of delayed transplanting twenty one days old seedlings were transplanted at 2-3 seedlings per hill. Flexible wire rope and colored cloth strips were used at specific interval as per the desirable spacing for maintaining the distance between plant and rows during transplanting operation. Fertilizer application was done @ of 80:40:40 kg NPK $\mathrm{ha}^{-1}$ in the form of Urea, Single super phosphate (SSP) and Muriate of Potash (MoP). One-third dose of nitrogen, entire dose of phosphorus and half of the potash were applied basally, remaining nitrogen was applied in equal splits during active tillering (30 DAP) and panicle initiation stage (65 DAP), respectively and the remaining half of potash was applied during panicle initiation stage. Urea and MoP were broadcasted along the field and SSP was incorporated in the root zone of plants. Weedicide (Butachlor) was sprayed @ 4ml/1 of water two days after transplanting the crop in the main field, followed by hand weeding at 40 DAP to keep the experimental plots weed free during the critical crop growth stages. Data on plant height, panicle length, number of effective tillers per plant and grain yield were recorded from 5 randomly selected plants from each treatment.

\section{Statistical Analysis}

The data collected for different characters were subjected to statistical Analysis and subsequent $\mathrm{F}$ test appropriate to the experimental design (Cochram and cox. 1950). The standard error of mean (SEm \pm and difference $(\mathrm{CD})$ at 5 percent and significance level was worked out for the different parameters. 


\section{Results and Discussion}

\section{Number of Panicles $\mathbf{m}^{-2}$}

The detail introspection of the data presented in Table2clearly indicated that the total number of panicle $\mathrm{m}^{-2}$ were differed significantly among different rice establishment methods and dates of sowing where it is at par in both the rice cultivars.

The maximum number of panicle $\mathrm{m}^{-2}$ (458) were noticed in transplanted paddy which was almost 29 and 52\% higher than that observed in unpuddled transplanted and direct seeded paddy, respectively. Similarly early sown crop registered more number of panicles (389) than the crop planted on $11^{\text {th }}$ July.

\section{Number of filled grain panicle}

The observed data on number of filled grains per panicle presented in Table 2 revealed that there was significant variation among different planting methods, dates of sowing and the rice genotypes. The maximum number of filled grains per panicle (109) was recorded from puddled transplanted Paddy registering 23and $45 \%$ higher filled grain number then that obtained from unpuddled transplanted and direct seeded paddy crop, respectively. However, the differences were not so pronounced with date of planting and rice genotypes. Only 9\% and 12\% higher filled grains per panicle registered with early planted crop and rice genotype, respectively as compared to their counterpart.

Table.1 Detail of treatment combinations.

\begin{tabular}{|l|l|l|}
$\begin{array}{l}\text { Three establishment methods } \\
\text { (main plot) }\end{array}$ & $\begin{array}{l}\text { Dates of Sowing: Two (sub } \\
\text { plot) }\end{array}$ & Variety: Two (sub-sub plot) \\
\hline M1-Line sowing (direct seeded) & $\mathbf{D}_{1}-27$ June & V1- Naveen \\
\hline M2-Transplanting (unpuddled) & $\mathbf{D}_{2}-11$ July & V2-Pooja \\
\hline M3-Transplanting (puddled) & &
\end{tabular}

Table.2 Number of panicle, total grain/panicle, test weight and grain yield as affected by different establishment methods, dates of sowing and varieties

\begin{tabular}{|c|c|c|c|c|}
\hline Management & No of panicle/m ${ }^{-2}$ & $\begin{array}{l}\text { Total filled grains } \\
\text { /panicle }\end{array}$ & Test weight (g) & $\begin{array}{c}\text { Grain yield } \\
\text { kg/ha }\end{array}$ \\
\hline M1 & 302 & 75 & 21.4 & 2440 \\
\hline M2 & 356 & 89 & 21.8 & 2964 \\
\hline M3 & 458 & 109 & 23.0 & 3483 \\
\hline SEm+ & 10.0 & 1.9 & 0.25 & 62.6 \\
\hline $\mathrm{CD}(0.05)$ & 31.6 & 6.2 & 0.81 & 197.4 \\
\hline \multicolumn{5}{|l|}{ Date of sowing } \\
\hline D1 & 389 & 95 & 22.7 & 3117 \\
\hline D2 & 354 & 87 & 21.4 & 2808 \\
\hline SEm+ & 8.2 & 1.6 & 0.21 & 51.1 \\
\hline $\mathrm{CD}(0.05)$ & 25.8 & 5.0 & 0.66 & 161.1 \\
\hline \multicolumn{5}{|l|}{ Variety } \\
\hline V1 & 362 & 86 & 22.5 & 2856 \\
\hline $\mathrm{V} 2$ & 382 & 96 & 21.6 & 3069 \\
\hline SEm+ & 15.1 & 2.8 & 0.17 & 59.1 \\
\hline $\mathrm{CD}(0.05)$ & NS & 8.8 & 0.53 & 182.2 \\
\hline
\end{tabular}




\section{Test weight (g)}

The data presented on 1000 grain weight of rice genotypes as influenced by various planting methods and dates of sowing are presented in the Table 2It clearly indicated that heavier grains $(23 \mathrm{~g} / 100 \mathrm{grain})$ recorded from puddled transplanted rice which was superior to other two planting methods. Among two dates of planting. Higher test weight was obtained in early planted as compared to the late planting. However the grain weight was relatively higher in cv, Naveen than to the test weight of cv. Pooja. The interaction effect were non-significant.

\section{Grain yield (kg/ha)}

The grain yield of rice is a function of total number of panicles, number of grains per panicle and the grain weight, which was significantly influenced by the planting methods, dates of sowing and the rice cultivars (Table 2). The transplanted puddled rice registered maximum grain yield of $3438 \mathrm{~kg} / \mathrm{ha}$ which was almost $17.5 \%$ more than unpuddled transplanted rice and $42.7 \%$ more than direct seeded rice $2440 \mathrm{~kg} / \mathrm{ha}$. The early sown crop $\left(27^{\text {th }}\right.$ June) produced maximum grain yield $(3117 \mathrm{~kg} / \mathrm{ha})$ with yield advantage of almost 19\% than that crop sown on 11 July $(2808 \mathrm{~kg} / \mathrm{ha})$. The highest grain yield was obtained with $c v$. Pooja (3070kg/ha) which was almost $7.5 \%$ higher than that observed with $c v$. Naveen $(2856 \mathrm{~kg} / \mathrm{ha})$. Interaction between varieties and dates of sowing was found non-significant.

From the results observed in this experiment, it can be concluded that after puddled transplanting of rice seedlings enhances the performance of rice varieties through producing strong and fertile tillers, vigor plants and good stand of crops. All the yield attributing characters number of panicles $\mathrm{m}^{-2}$, number of grains panicle ${ }^{-1}$ and test weight were maximum in plants planted after puddling over the unpuddled transplanting and direct sowing. The treatment also produced maximum grain yield $(3483 \mathrm{~kg}$ ha $\left.{ }^{1}\right)$. Similarly the early sown crop and $c v$. Pooja registered better yield attributing parameters which ultimately registered in higher crop yield than their counterpart of late planting and $c v$. Naveen, respectively.

\section{References}

Aggarwal, G.C, Sidhu, S, Sekhon, N.K., Saadhu, S.K, Sor, H.S.1995. Puddling and $\mathrm{n}$ management effect crop response in a rice -wheat cropping system. Soil and Tillage Reserch. 39: 129-139.

Balasubramanian, V. and Hill, J.E. 2002. Direct seeding of rice in Asia: emerging issues and strategic research need for the $21^{\text {th }}$ century. Proceeding of the international workshop on direct seeding in Asian rice systems: Strategic Research issues Opportunities, 25-28 January. 2002. Bangkok, Thailand, Los Banos (Philippines): International Rice Research Institute. PP. 24-25.

C AC P. Commission for agricultural price policy. 2015. Agricultural policy for cereals and Pulses. 2015.

Carman, K. 1996. Effect of different tillage systems on soil properties and wheat yield in middle Anatolia. Soil and Tillage Reserch, 40: 204-207.

Chauhan, B.S and Johnson, D.E. 2009. Influence of tillage system on weed seedling emergence pattern in rainfed rice Soil and Tillage Reserch. 106: 1521.

Farooq, M., (2011). Rice direct seeding: Experiences, challenges and opportunities- a review. Soil and Tillage Res., 111: 87-98.

Kent, R.J and Johnson, D.E. 2001. Influence of flood depth and duration on biology 
and growth of low land rice weed, Coledivoire, crop prof. 20: 691-694

Kirchhof G., Priyono, S., Utomo, W.H., Adisarwanlo, T., Daccaay, E.V. and So, H.B. 2000. The effect of soil puddling on the soil physical properties and the growth of rice and post rice crops. Soil and Tillage Reserch. 56: 37-50.

Kumar, V and Ladha, J.K. 2011. Direct seeding of rice; recent development and future research needs. Advances in Agronomy. 111: 297-413.
Mukesh Singh I, Pannu RK, Prasad D and Asha Ram. 2013. Effect of different transplanting dates on yield and quality of basmati rice (Oryza sativa) varieties, Indian Journal of Agronomy, 58 (2): 256-258.

Poonamperuna, F.N. 1972. The chemistry of submerge soils. Advances in Agronomy.24:29-96.

Sarawat, K.L. 2005. Fertility and organic matters in submerge rice soils. Current Science. 88(5) 735-739.

\section{How to cite this article:}

Kamlesh Kumar Sahu, Bhirendra Kumar, Uttam Kumar Diwan and Pasupalk, S. 2018. Effect of Different Plant Establishment Techniques on Yield and Yield Components of Rice (Oryza sativa L.) Varieties in East \& South East Coastal Plain of Odisha, India. Int.J.Curr.Microbiol.App.Sci. 7(07): 4198-4203. doi: https://doi.org/10.20546/ijcmas.2018.707.490 